June 1992

\title{
Women's Psychology
}

Jodi Halpern, M.D.

University of California at Los Angeles

Follow this and additional works at: https://jdc.jefferson.edu/jeffjpsychiatry

Part of the Psychiatry Commons

Let us know how access to this document benefits you

\section{Recommended Citation}

Halpern, M.D., Jodi (1992) "Women's Psychology," Jefferson Journal of Psychiatry. Vol. 10 : Iss. 2 , Article 12.

DOI: https://doi.org/10.29046/JJP.010.2.009

Available at: https://jdc.jefferson.edu/jeffjpsychiatry/vol10/iss2/12

This Article is brought to you for free and open access by the Jefferson Digital Commons. The Jefferson Digital Commons is a service of Thomas Jefferson University's Center for Teaching and Learning (CTL). The Commons is a showcase for Jefferson books and journals, peer-reviewed scholarly publications, unique historical collections from the University archives, and teaching tools. The Jefferson Digital Commons allows researchers and interested readers anywhere in the world to learn about and keep up to date with Jefferson scholarship. This article has been accepted for inclusion in Jefferson Journal of Psychiatry by an authorized administrator of the Jefferson Digital Commons. For more information, please contact: JeffersonDigitalCommons@jefferson.edu. 


\title{
Book Reviews
}

\section{Women's Psychology}

\author{
FEMALE PSYCHOLOGY, AN ANNOTATED PSYCHOANALYTIC BIBLIOGRAPHY \\ edited by Eleanor Schuker, M.D., and Nadine A. Levinson, D.D.S., F.A.C.D. \\ New Jersey, The Analytic Press \\ 1991, 678 pp.
}

\section{by Jodi Halpern, M.D.}

Twenty years after interest in women's studies has had major impact on academia and professional psychology training, psychoanalytic institutes and psychiatric residencies remain surprisingly unaffected. Few residencies or analytic institutes teach specialized courses in women's psychology, or include considerations of gender in other courses. Residents lack a basic understanding of female development through the life cycle, and of the impact of gender on personality, diagnosis and treatment and there is a lack of appreciation for how gender impacts upon the process of psychotherapy.

In the mid 1980's, the Workshop on Issues for Women of the Council on Psychoanalytic Education (COPE) responded to the need for education on female psychology. Some of the members asked their institutes to provide courses on women's psychology and were told that there was insufficient psychoanalytic literature to justify a course on women. This inspired Eleanor Schuker and Nadine Levinson, with the support of Barbara Deutsch and Helen Meyers, the chairs of the COPE workshop, to spend five years reviewing the literature on women and psychoanalysis. The result of their inspired efforts, which involved the collaboration of sixty colleagues, is this comprehensive bibliography. The more than two thousand books and articles clearly annotated here, covering psychoanalytic views of women from Freud to the present time, serve as a resounding response to the claim that there is an insufficient literature on women and psychoanalysis.

Female Psychology, An Annotated Psychoanalytic Bibliography is an extensively researched and clearly written text and is unusually user-friendly. It is divided into five sections: "Historical Views," "Developmental Perspective," "Female Sexuality and Character Psychopathology," "Clinical Concepts," and "Reading Lists." The section on "Historical Views" separately lists historical papers and modern commentaries on significant figures in the history of psychoanalysis, to meet different research needs. Within each chapter the annotations are listed chronologically rather than alphabetically so that users can have a temporal reference to chart the development of ideas 
on each topic. The annotations are lucid and go into sufficient depth to allow the reader to create conceptual schemes of the topic and of the author's theoretical orientation. For example, one sees how Klein, Horney and Fenichel influenced each other's conceptions of the development of female sexuality. Each chapter begins with a commentary that describes the development of ideas and points out areas of current controversy. Overall, these commentaries were thought-provoking but brief. Future editions of this bibliography could benefit from allocating more room for these discussions.

The topics of the twenty-eight chapters reflect the marriage of traditional psychoanalytic views of women's issues, with more recent conceptions of women's psychology. For example, the section on female sexuality and character psychopathology, includes chapters on masochism, narcissism, eating disorders, sexual abuse, gender identity disorders, paraphilias and ego-dystonic homosexualities. This spirit of broadening rather than criticizing the categories into which psychoanalysis has placed women's concerns is welcome.

By juxtaposing recent research on women from outside psychoanalysis with traditional analytic papers, this text invites psychoanalysts to rethink many basic conceptions of women. For example the introduction to the chapter on sexuality divides the topic as follows: first, historically important papers on femininity, sexual identity and sexual drives; second, recent empirical research on the female sexual response cycle including masturbation, arousal patterns and orgasm; third, psychological aspects of sexual functioning and erotic excitement; fourth, writings on feminine body image and the psychic representation of the female genitals and related conflicts; and fifth global theories of sexuality, including papers on gender identity and femininity. The effect of these sub-categories is to raise several questions in the reader's mind. For example, which aspects of the historical writings derive from faulty conceptions of the female sexual response cycle and of the psychic representation of body image and the female genitals, and which aspects are still conceptually viable today? What particular contribution can psychoanalytic theory make to understanding and distinguishing between the development of gender identity/ femininity and the development of object choice/styles of erotic excitement? This chapter makes it possible to do creative research on these and myriad other questions.

The section entitled "Clinical Concepts" illuminates the interdependency of women's roles in society with the role of the therapist/analyst by focusing on gender issues in transference and countertransference and on the pregnant analyst. Psychiatric residents, who are most often taught about transference and countertransference in terms of the dyad of male therapist and female patient, will be particularly interested in this section. The first chapter covers alternative therapeutic dyads, and includes papers on erotized transference involving the female therapist. The influence of gender in the supervisory relationship is also considered. The second chapter on the pregnant analyst addresses a very common occurrence in the lives of psychiatric residents and recent graduates that is rarely taught about in residency training. Women residents will find in both these chapters an abundance of refer- 
ences that illuminate their experiences as therapists, and provide the basis for further research.

Most importantly, this text offers an irresistible invitation to institutes and residencies to teach courses on women's psychology. In the final chapter the authors give comprehensive course outlines for four different kinds of courses: a twelve seminar course for psychoanalytic candidates, advanced psychiatric residents and psychologists; a thirteen seminar course for undergraduate study; a two-day course for practicing clinicians; and an eighteen session seminar with a focus on current controversies for advanced psychoanalytic trainees and graduates of analytic institutes. These outlines are designed exceptionally well and ready for practical use, needing only the spark of interest to materialize into exciting courses.

In summary, every residency and psychoanalytic institute in this country should have a copy of Female Psychology, An Annotated Psychoanalytic Bibilography. Eleanor Schuker, Nadine Levinson and their colleagues are to be congratulated for producing a text that promises to revolutionize psychoanalytic and psychiatric education. 